\title{
CATERING TO CATERERS: EXPECTATIONS AND SATISFACTION OF RESTAURANT PARTNERS FROM FOOD ONLINE ORDER AND DELIVERY (FOOD) OPERATOR
}

\author{
Palaniappan Sellappan \\ Ad-Hoc Faculty, National Institute of Technology, Tiruchirappalli, Tamilnadu, India \\ Scopus Id : 57214316660, Orcid Id : 0000-0002-2890-1412 \\ Dr. Kavitha Shanmugam \\ Associate Professor, School of Management, SRM Institute of Science \& Technology, \\ Kattankulathur, Chengalpattu, Tamilnadu, India
}

\begin{abstract}
Purpose

Technology-enabled $U$ commerce revolution is creating a tectonic shift in restaurant service. In this transitionary phase, appreciating the key "take-away" expectations of restaurant partners will strengthen the model.

\section{Design/Methodology/Approach}

This descriptive study is administered through convenience sampling of 123 Restaurant Partners of FOOD Apps. Key expectations from these food delivery services companies were identified and underlying dimensions exposed. Identified attributes are examined through Revised IPA.
\end{abstract}

\section{Findings}

The research exhibits mouth-watering toppings in the business association like online presence, wider reach, enhanced sales, and customer management. It also portrays longing demands of restaurant partners.

\section{Originality/Value}

Among the four participants of this business model, restaurant partners play a vital role, and this work is the primal attempt to delve into the "take-away" expectations of restaurant partners. The present study gives a first-hand view on their expectations.

\section{Implications}

This study enables practicing managers of FOOD firms to work on the strong and weak points and enable them to device appropriate strategy. This will result in manifesting fruitful association between technology giants and established restaurant houses. 
Key words: Restaurant Partners, FOOD APP, Food aggregator, online ordering, revised importance-performance analysis.

Cite this Article: Palaniappan Sellappan and Dr. Kavitha Shanmugam, Catering to Caterers: Expectations and Satisfaction of Restaurant Partners from Food Online Order and Delivery (Food) Operator, International Journal of Management, 11(12), 2020, pp. 2637-2659.

http://iaeme.com/Home/issue/IJM?Volume=11\&Issue $=12$

\section{INTRODUCTION}

\subsection{Prelude}

M-Commerce revolution successfully graduated from the infant stage, and newer variant of Mcommerce via U-commerce has brought out many new business models. Online to offline $(\mathrm{O} 2 \mathrm{O})$ ventures like food delivery, travel, hospitality, fin-tech, etc., are testing the waters every day. Online to offline $(\mathrm{O} 2 \mathrm{O})$ model connects the vendors and customers through online and offline networks. (Chen, Huang, Chen, and $\mathrm{Ku}, 2015$; Xiao \& Dong, 2015). These MCommerce applications are emerging as game-changers. (Liu, Batra, \& Wang, 2017; Liu, Xiao, Lim, \& Tan, 2017). Tech-savvy population is accepting and adopting newer business models. Market size of technology-based sharing economy is projected to reach $\$ 335$ billion in 2025 (Tabcum, 2019). O2O business is witnessing phenomenal growth in time-bound perishable services (Babu, 2016).

Food Online Order and Delivery application (FOOD app) is a business model in $\mathrm{O} 2 \mathrm{O}$ commerce which connects the customer and the restaurant through online ordering and offline delivery network. This model of M-commerce business application is revolutionizing the way we eat. This business model is gaining customer acceptance and capturing market across the world (Hirschberg, Rajko, Schumacher, \& Wrulich, 2016).

Initial growth in online order and delivery of food and beverages was led by restaurant owned delivery service operated by outlets like Pizza Hut, McDonald's, Domino's Pizza, Kentucky Fried Chicken, etc. Later $3^{\text {rd }}$ party owned applications started to emerge as multi restaurant intermediaries (Yeo, Goh, \& Rezaei, 2017). In the $3^{\text {rd }}$ party owned applications, there are two formats. (1) Restaurant-to-consumer (R2C) delivery where restaurants will take care of delivery operation and (2) Platform-to-consumer (P2C) delivery where intermediaries will take care of delivery. P2C format is attracting more players. Globally brands like Uber eats, Grabhub, Postmates, DoorDash, Tapingo, Snapfinger/Kudzu, Caviar, JustEat, Deliveroo, Foodora, Delivery Hero, Ele.me, Meituan waimai, Baidu Waimai, Yoggio, Baemin, Wolt, Delivery Chef, etc., are functioning. In India, food-tech start-ups such as Zomato, Swiggy, Ubereats, Yummybay, etc., have substantially changed the landscape of food and beverage industry (Munshi, 2019).

The FOOD app business model is passing through crucial adolescent stage. FOOD operator's revenue is expected to grow at an annual average of more than $20 \%$, and by 2030 , online to offline market is projected as a $\$ 365$ billion market across the world (Cheng, A., 2018). It is attracting a lot of attention from venture capital, private equity investors, and at the same time mergers, acquisitions, and shutting down are also happening (Meenakshi \& Sinha, 2019). In this vibrant stage, FOOD operators need to fine-tune their business model to ensure sustainability (Bajaj \& Mehendale, 2016). They should look at the expectations of all the stakeholders to dish out sustainable business. 
Restaurant partners who are hitherto dominating the food business landscape are not just a producer, but they are the key ingredients in this whole recipe. They are one among the four pillars of this business model. Restaurant houses are not feeling comfortable in associating with FOOD operators. They are motivated by the incremental revenue through FOOD app orders (Wirth, 2018). At the same time, they are considering FOOD operators as potential challengers Romeo, 2018). Restaurant houses are concerned with a shrinking profit margin (Collison, 2020) and loss of customer allegiances (Meyersohn, 2018). Restaurants led by National Restaurants Associations of India launched a logout campaign and expressed their dissatisfaction over terms of engagement (Tandon, 2019). In this scenario, appreciating the "Take-Home" expectations of restaurant partners will result in cooking a well-balanced success recipe.

\section{RESEARCH STUDIES ON FOODAPP BUSINESS MODEL}

FOOD apps are disrupting established equations of food and beverage industry. Every technological disruption comes with a new set of unanticipated challenges in socio-economic space that need to be studied (Coates, 2001).

The authors surveyed the available literature on FOOD APP, online ordering, O2O platform, etc., and classified them into four broad categories.

\section{Nature of FOOD app Segment}

Meenakshi \& Sinha (2019) studied the evolution, competition and future direction of FoodTech business in India. Munshi (2019) conceptually evaluated the working and structure of the FOOD App segment in India. Bajaj \& Mehendale (2016) examined the critical success factors for the viability of FOOD Apps. Li, Mirosa, \& Bremer (2020) analyzed the sustainability of the segment.

\section{Technology \& Operational Efficiency}

Tobing (2016); Al Abid \& Karim (2017) worked on the technological side of FOOD app. Pigatto, Machado, Negreti, \& Machado (2017) analysed the performance of online FOOD service companies in Brazil and studied their website contents. Liu, Guo, Du, Yu, Zhang, \&Chen (2017); Correa et al., (2019) evaluated the delivery efficiency of FOOD app firms. Pan, $\mathrm{Wu}$, and Olson (2017) developed a model for service recommendation in O2O platform.

\section{Customer Satisfaction}

Yang, \& Peterson, (2002); Mozeik, Beldona, Cobanoglu, and Poorani (2009); Wu, Zhao, and Tzeng (2015); Bagla \& Khan (2017); Yeo et al., (2017); Kapoor \& Vij (2018); Kang \& Kim (2018); Chakraborty (2019); Cho, Bonn,\& Li(2019); Roh \& Park (2019); Ray, Dhir, Bala, and Kaur (2019); Verma (2020) explored the customer adoption and expectations in online food ordering.

\section{Restaurant Perception}

Research attention towards restaurant partner's aspirations in this model are sparse. Kimes \& Laqué (2011); Mody, Gomez, Searle, Muller, \& Titherington (2018) appraised the utility and efficiency of an online ordering system for restaurants. He, Han, Cheng, Fan, \& Dong (2019) tested the influence of Food quality and location strategy of restaurants in online order and offline delivery model. Gao \& Su (2017) evaluated the online and offline ordering system by analysing wait time and capacity utilisation data in tandem queuing network and found that online ordering is beneficial to customers as well as restaurants. Recognising and appreciating restaurant partner's importance preferences will provide the essential bonding in the FOOD business model. 


\section{Statement of the Problem}

FOOD operators are intelligently stirring the technological myths of mobile application technology and the physical domination of established restaurants. This budding segment is passing through a turbulent phase of development. Appreciating the key expectation of various stakeholders, more particularly, expectations of Restaurant Partners, will result in leveraging the strength of all stakeholders towards delighting the customers. This article strives to pop-out key expectations of restaurant partners through factor analysis and revised importanceperformance analysis.

\section{IMPORTANCE-PERFORMANCE THEORY LITERATURE REVIEW}

Ever since Martilla and James (1977) proposed the Importance-Performance theory, it is widely used to identify key expectations to magnify service quality in the market place. It is employed to study satisfaction in several fields such as automotive, food, healthcare, tourism, banking, education, etc. Importance-performance analysis (IPA) equips management to identify priority areas, and they can maximize the business outcome by diverting resources to them (O'Neill and Palmer, 2004).

Keyt, Yavas \& Riecken(1994) utilized IPA to study market positioning of restaurants. Ennew, Reed \& Binks, (1993) applied the importance-performance theory to study the key factors for improving service quality in the banking sector. Huang, Kuo, \&Xu (2009) evaluated the logistics service quality for retail delivery through the importance-performance study. Karthiyayini, Rajendran \& Kumaravel (2018) tested the service quality of laboratories using importance-performance analysis. Jeng, Snyder, and Chen(2019) used IPA to gather tourist perceptions, grievances and shortcomings on Taiwan as tourist destination Wyród-Wróbel \& Biesok (2017); Park, Bae, Han, Cheng, Kim, and Chang (2019) used IPA to identify key attributes for product development.

\section{RESEARCH GAP}

Among the limited research's studied in the emerging FOOD app segment, most of them concentrated on the general structure of the segment, operational efficiency, and customer adoption. In this four-party business model, appreciating important expectations of restaurant partners is a critical requirement to establishing synergy and sustainability.

Importance performance analysis is applied in several sectors, and key factors for service improvements were identified. The present study is directed towards enlisting the strategic expectations of restaurant partners through Importance-performance analysis.

\section{OBJECTIVES OF THE STUDY}

The present work tries to identify key satisfaction attributes of restaurant partners and their underlying dimensions. And it will delve into those attributes and dimensions to figure out vital expectations.

\section{RESEARCH METHODOLOGY}

The current study followed a descriptive research design. The study is carried on with a sample of 123 restaurants in Tiruchirappalli. Restaurant partners associated with all the 3 FOOD App brands, namely Zomato, Swiggy, and Uber eats, are collected, and from that, 130 restaurants are selected by using convenience sampling (Rial, Rial, Varela, and Real, 2008). Among them, 123 respondents properly replied. 
The researcher used a questionnaire schedule as the tool for data collection. The first part of the two-part questionnaire gathers demographic data of restaurant partners. Service offerings of FOOD operators are studied through interviews with 15 restaurant partners. Open-ended questions are raised with them regarding their association with FOOD apps, and 22 service attributes are identified. The identified attributes are framed as satisfaction attributes. Expert opinions were sought to crystallize those attributes, and finally, they were listed in the second part of the questionnaire. A pilot study is organized to check the validity and reliability of the questionnaire. Based on the outcome of pilot testing, 21 attributes were retained as satisfaction features. Restaurant Partner level of satisfaction on those features is collected through the Likert 7-point scale.

The collected data are summarised, and underlying dimensions are explored through Factor analysis. The identified attributes and extracted dimensions are plotted in the revised importance-performance matrix, and based on that, perceptions of restaurants are inferred.

\subsection{Traditional IPA}

In traditional Importance-Performance analysis (Fig.1), important service features are plotted against perceived performance. The resultant importance-performance space is divided into four quadrants, and key factors in each quadrant are analyzed.

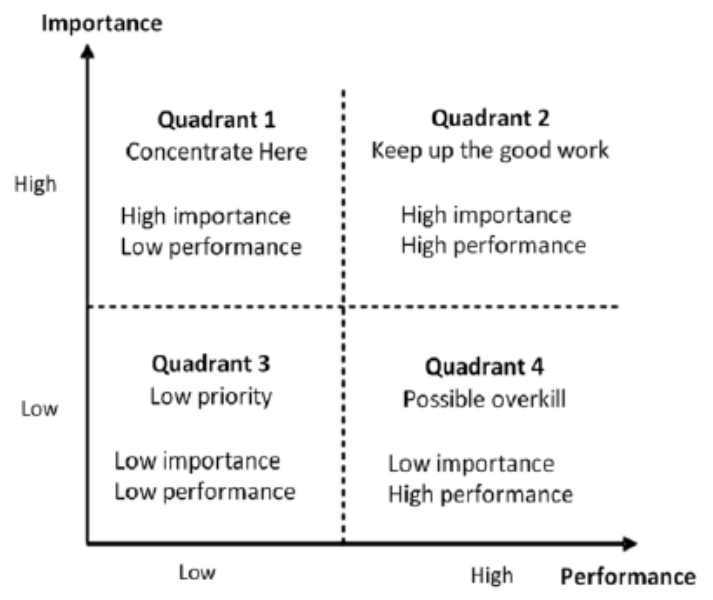

Figure 1 Traditional quadrant IPA matrix developed by Martilla and James (1977)

Quadrant 1, in the topmost left corner, will have high importance and low-performance attributes, which requires concentration. Quadrant 2, topmost right corner, will signify high importance as well as high performance. The good works in that quadrant need to be sustained. Quadrant 3, bottom left corner, portrays attributes with low importance and low performance, and they deserve less priority. The bottom left corner has Quadrant 4, which is made up of less important, but high-performance features, and it is termed as "possible overkill" quadrant (Lee, 2019).

The manner in which quadrants are divided will leads to several IPA grids. IPA grid divided on the basis of scale means is called Scale Centred IPA. If the cross-hair point is drawn on the basis of averages of attributes, it is called as Data Centred IPA (Pornprasit \& Rurkkhum, 2019). Analysis reveals that the classical model will place most of the attributes in the "keep Up" quadrant, which hamper the discrimination ability (Tonge \& Moore, 2007; Wyród-Wróbel \& Biesok, 2017).

Alternative IPA model (Fig.2) proposed by Abalo, Varela, and Manzano (2007) introduced a diagonal line in the traditional matrix. Along the diagonal line, the level of importance and satisfaction will be equal. Areas above the diagonal line, signifies, that the degree of importance is higher than the degree of satisfaction and they crave for attention. Areas below the diagonal 
line are demarcated as in traditional IPA. Further areas below the diagonal line can be divided on the scale means or by using data means. Researches reveal that when compared to the traditional model, the diagonal line model is providing better results (Bacon, 2003; Lee, 2019).

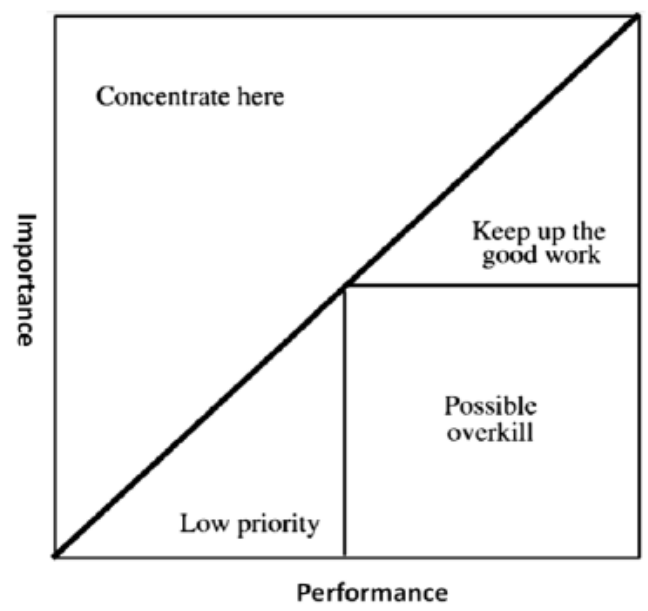

Figure 2 The Alternative IPA Matrix with Scale-Centred Diagonal Line (Abalo et al., 2007)

Previous studies reveal that each method has its own advantages and disadvantages. Based on the context of the study, the appropriate method has to be chosen (Ormanovic et al., 2017). The researcher has used both the Data Centred Importance-Performance grid and Diagonal and Scale Centred Importance-Performance grid to explore the key attributes and dimensions.

\subsection{Revised IPA}

Collection of importance and satisfaction, perceptions of the respondents directly from them will encounter causal effect relationship between importance and satisfaction variables and it will have multi-collinearity issue. Three-factor theory states that service attributes could be categorized into three types, namely, (1) Basic services if not present will dissatisfy, (2) Performance attributes, if present will not create much impact, and (3) Excitement factors if present will enhance satisfaction (Feng, Mangan, Wong, Xu, and Lalwani,2014). Thus, the relationship between attribute importance and satisfaction will be asymmetrical and non-linear for basic and excitement factors, and it will be symmetric for performance factors. Based on this, the causal relationship between importance attributes and satisfaction level is established (Matzler, Sauerwein, \& Heischmidt, 2003; Deng, Kuo, \& Chen, 2008; Lin, Chan, \& Tsai, 2009). To avoid those issues, Wei-jaw Deng (2007) proposed a Revised Importance Performance analysis (Fig.3). He computed the implied importance and plotted it along with explicit satisfaction in the Importance-Performance space.

In this method, initially, all satisfactions attribute variables are transformed into the natural logarithm form, which captures the sensitivity in the variable. Then the partial correlation coefficient between natural logarithmic attributes' satisfaction and overall customer satisfaction is computed. Computed partial correlation is the implied importance of that attribute. (Ku and Mak, 2017) 
Palaniappan Sellappan and Kavitha Shanmugam

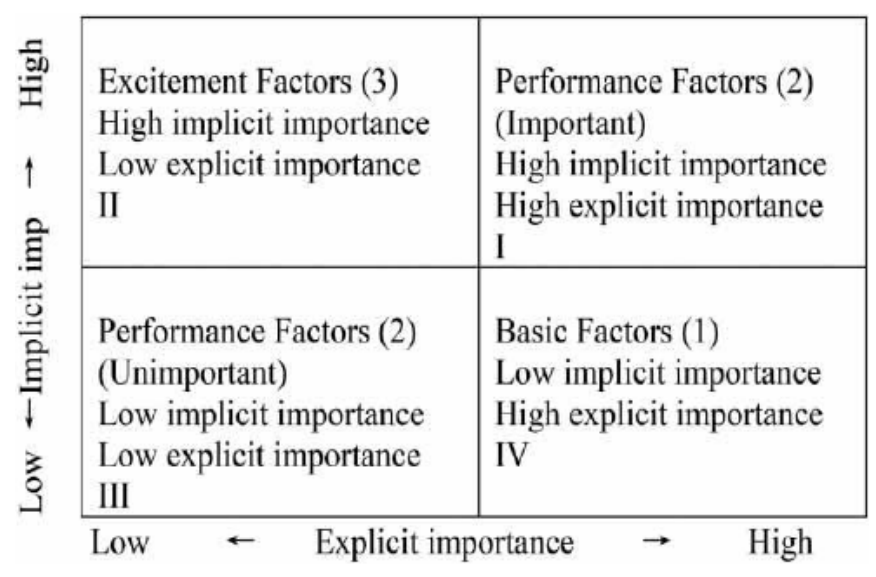

Figure 3. IPA with three-factor theory.

Source: adapted from Matzler et al. (2003), Deng et al. (2008), Lin et al. (2009).

Schroeder, Cornicelli, Fulton, and Merchant (2018) deployed revised IPA to study hunter satisfaction. $\mathrm{Ku}$ and Mak (2017) performed a revised IPA to measure tourism satisfaction. Jeon, Lee, and Kim, (2017) explored the productivity obstacle factors for chemical plant through revised IPA and suggested improvement plans and measures. Previous studies show that the revised-IPA method minimizes the latent subjective effects (Hongli, 2018). In the present study, the researcher computed the implicit importance and constructed the revised importanceperformance grid to identify decisive expectations.

\section{DATA ANALYSIS}

This section presents the statistical analysis carried out.

\subsection{Demographic Profile}

Among the 123 respondents, $32 \%$ of restaurants (39 restaurants) are young firms functioning for ten years and below. $41 \%$ of restaurants (51 restaurants) are functioning for 11-20 years, and $27 \%$ of restaurants (33 restaurants) are in the business for more than 20 years. $77 \%$ of the restaurants (95 restaurants) are functioning as standalone outlets, while the other $23 \%$ (28 restaurants) are having branches. Maximum of 59\% of restaurants ( 73 restaurants) score an average customer rating between 4.1 to 4.3 out of 5, 21\% of restaurants ( 26 restaurants) scored customer rating above 4.3 , and $20 \%$ of restaurants ( 24 restaurants) score customer rating below 4.1

\subsection{Perceived level of Satisfaction for Attributes}

The following table (Table 1) reveals the frequency statistics of 21 identified satisfaction attributes. 
Catering to Caterers: Expectations and Satisfaction of Restaurant Partners from Food Online Order and Delivery (Food) Operator

Table 1 Descriptive Statistics

\begin{tabular}{|l|l|c|c|c|}
\hline \multicolumn{1}{|c|}{ Code } & \multicolumn{1}{c|}{ Attributes } & $\begin{array}{c}\text { Mean } \\
\text { Satisfaction }\end{array}$ & $\begin{array}{c}\text { Std. } \\
\text { Deviation }\end{array}$ & Rank \\
\hline BS1 & Delivery & 6.29 & .733 & 1 \\
\hline BS2 & Reliable service & 3.52 & .739 & 16 \\
\hline BS3 & Timely service & 5.42 & .768 & 6 \\
\hline BS4 & order taking & 4.15 & .725 & 11 \\
\hline BS5 & Online presence & 5.71 & .956 & 4 \\
\hline CN1 & Attracting more customers & 5.11 & .822 & 7 \\
\hline CN2 & sales enhancement & 6.66 & .493 & 2 \\
\hline CN3 & Competitive advantage & 3.40 & .733 & 18 \\
\hline CN4 & Customer rating & 5.50 & .670 & 5 \\
\hline BA1 & Restaurant led promotion & 3.62 & .696 & 15 \\
\hline BA2 & Promotion schemes & 1.98 & .701 & 20 \\
\hline BA3 & Revenue sharing & 2.02 & .633 & 19 \\
\hline BA4 & Stable T\&C & 4.10 & 1.067 & 12 \\
\hline CRM1 & Acting as customer interface & 4.44 & .655 & 10 \\
\hline CRM2 & Ownership of customer data & 3.50 & .658 & 17 \\
\hline CRM3 & Customer loyalty building & 1.48 & .632 & 21 \\
\hline IM1 & Order clarity & 4.89 & .715 & 8 \\
\hline IM2 & Order scheduling & 3.86 & .669 & 13 \\
\hline IM3 & Order data management & 5.93 & .642 & 3 \\
\hline OT1 & Acceptable T\&C & 3.70 & 1.890 & 14 \\
\hline OT2 & Credit transfer & 4.88 & 1.944 & 9 \\
\hline
\end{tabular}

From the above table, it is evident that, with an average score of 6.29 , delivery function scores the highest satisfaction. Customer loyalty-building scored 1.48 average, and it is the low scored satisfaction attribute.

\subsection{Factor Analysis}

Factor analysis is conducted to verify the construct validity. KMO and Bartlett's test (Table 2) is performed to check the validity.

Table 2 KMO and Bartlett's Test

\begin{tabular}{|l|l|l|}
\hline Kaiser-Meyer-Olkin Measure of Sampling Adequacy. & .685 \\
\hline Bartlett's Test of Sphericity & Approx. Chi-Square & 1288.861 \\
\cline { 2 - 3 } & df & 210 \\
\hline & Sig. & .000 \\
\hline
\end{tabular}

Keiser-Meyer-Olkin test value is .685, and p-value in Bartlett's test of sphericity is zero.

Identified attributes are subjected to factor analysis. The researcher employed principal component factor analysis with varimax rotation. At the end of five iterations performed by SPSS 23.0, Six factors are extracted. Those six factors explain $71.9 \%$ of cumulative variance. All attributes with an eigenvalue of 0.400 are retained. Finally, 20 attributes are placed under six dimensions (Table $3 \& 4$ ).

Table 3 Total Variance of Extracted Factors 
Palaniappan Sellappan and Kavitha Shanmugam

Total Variance Explained

\begin{tabular}{|c|c|c|c|c|c|c|c|c|c|}
\hline \multirow{2}{*}{ Component } & \multirow{2}{*}{$\begin{array}{c}\begin{array}{c}\text { Initial } \\
\text { Eigenval } \\
\text { ues }\end{array} \\
\\
\text { Total }\end{array}$} & \multicolumn{5}{|c|}{ Extraction Sums of Squared Loadings } & \multicolumn{3}{|c|}{$\begin{array}{l}\text { Rotation Sums of } \\
\text { Squared Loadings }\end{array}$} \\
\hline & & $\begin{array}{c}\% \text { of } \\
\text { Varianc } \\
\mathrm{e}\end{array}$ & $\begin{array}{c}\text { Cumulati } \\
\text { ve } \%\end{array}$ & Total & $\begin{array}{c}\% \text { of } \\
\text { Variance }\end{array}$ & $\begin{array}{c}\text { Cumulat } \\
\text { ve } \%\end{array}$ & Total & \begin{tabular}{|c|}
$\%$ of \\
Varianc \\
$\mathrm{e}$
\end{tabular} & $\begin{array}{c}\text { Cumul } \\
\text { ative } \\
\%\end{array}$ \\
\hline Delivery & 4.206 & 20.030 & 20.030 & 4.206 & 20.030 & 20.030 & 3.718 & 17.703 & 17.703 \\
\hline Reliable service & 2.603 & 12.395 & 32.425 & 2.603 & 12.395 & 32.425 & 2.575 & 12.260 & 29.963 \\
\hline Timely service & 2.445 & 11.645 & 44.070 & 2.445 & 11.645 & 44.070 & 2.462 & 11.722 & 41.686 \\
\hline order taking & 2.281 & 10.864 & 54.933 & 2.281 & 10.864 & 54.933 & 2.413 & 11.490 & 53.175 \\
\hline Online presence & 1.947 & 9.273 & 64.207 & 1.947 & 9.273 & 64.207 & 2.156 & 10.267 & 63.442 \\
\hline Attracting more customers & 1.629 & 7.755 & 71.962 & 1.629 & 7.755 & 71.962 & 1.789 & 8.519 & 71.962 \\
\hline sales enhancement & 0.930 & 4.426 & 76.388 & & & & & & \\
\hline Competitive advantage & 0.716 & 3.412 & 79.800 & & & & & & \\
\hline Customer rating & 0.611 & 2.908 & 82.708 & & & & & & \\
\hline Restaurant led promotion & 0.575 & 2.736 & 85.444 & & & & & & \\
\hline Promotion schemes & 0.471 & 2.243 & 87.687 & & & & & & \\
\hline Revenue sharing & 0.408 & 1.941 & 89.629 & & & & & & \\
\hline Stable T\&C & 0.393 & 1.872 & 91.500 & & & & & & \\
\hline Acting as customer interface & 0.347 & 1.654 & 93.154 & & & & & & \\
\hline Ownership of customer data & 0.290 & 1.380 & 94.534 & & & & & & \\
\hline Customer loyalty building & 0.270 & 1.287 & 95.821 & & & & & & \\
\hline Order clarity & 0.250 & 1.191 & 97.012 & & & & & & \\
\hline Order scheduling & 0.195 & 0.928 & 97.940 & & & & & & \\
\hline Order data management & 0.170 & 0.807 & 98.748 & & & & & & \\
\hline Acceptable T\&C & 0.163 & 0.778 & 99.525 & & & & & & \\
\hline Credit transfer & 0.100 & 0.475 & 100 & & & & & & \\
\hline
\end{tabular}

Table 4 Factors Extracted

\begin{tabular}{|c|c|c|c|c|c|c|}
\hline \multicolumn{7}{|c|}{ Rotated Com ponent Matrix ${ }^{a}$} \\
\hline & \multicolumn{6}{|c|}{ Component } \\
\hline & 1 & 2 & 3 & 4 & 5 & 6 \\
\hline Delivery & 0.859 & & & & & \\
\hline Reliable service & 0.774 & & & & & \\
\hline Timely service & 0.799 & & & & & \\
\hline order taking & 0.876 & & & & & \\
\hline Online presence & 0.857 & & & & & \\
\hline Attracting more customers & & & & & 0.782 & \\
\hline sales enhancement & & & & & 0.784 & \\
\hline Competitive advantage & & & & & 0.792 & \\
\hline Customer rating & & & & & 0.434 & \\
\hline Restaurant led promotion & & 0.794 & & & & \\
\hline Promotion schemes & & 0.760 & & & & \\
\hline Revenue sharing & & 0.618 & & & & \\
\hline Stable T\&C & & 0.774 & & & & \\
\hline Acting as customer interface & & & & 0.848 & & \\
\hline Ownership of customer data & & & & 0.873 & & \\
\hline Customer loyalty building & & & & 0.912 & & \\
\hline Order clarity & & & 0.800 & & & \\
\hline Order scheduling & & & 0.935 & & & \\
\hline Order data management & & & 0.944 & & & \\
\hline Acceptable T\&C & & & & & & 0.880 \\
\hline Credit transfer & & & & & & \\
\hline \multicolumn{7}{|c|}{ Extraction Method: Principal Component Analysis. } \\
\hline \multicolumn{7}{|c|}{ Rotation Method: Varimax with Kaiser Normalization. ${ }^{a}$} \\
\hline Rotation converged in 5 iterat & & & & & & \\
\hline
\end{tabular}




\section{Factor Identification}

Based on the items included in each dimension in Table 4, Factors are named. Factor "One" consists of online presence, order taking, delivery, timely service, and reliable service, and it explains $17.7 \%$ of the total variance. All these are basic central activity of FOOD operators. This dimension is named "Core function." The second factor is made up of four factors: the restaurant-led promotions, promotion and offers, revenue sharing, and stable terms and conditions that explain $12 \%$ of the total variance. All these factors talk about the independence of the restaurant in business decision making. Hence this factor is names as Business autonomy.

The third factor comprises attributes like order clarity, order scheduling, and order data management, and they explain $11.7 \%$ of the total variance. It is christened as Order Management. Acting as a customer interface, owning customer data, and building customer loyalty are the attributes for the fourth factor, which explains $11.5 \%$ of the variance. All these items talk about customer relationship, and hence it is branded as Customer Relationship Management.

The fifth dimension, which accounts for $10 \%$ of variations, is built on customer augmentation, sales enhancement, user credit rating, and competitive advantage. All these attributes discuss the competitive strength due to synergy, and it is labeled as Synergic competitive strength. The final factor which explains another $8 \%$ of variations, is made up of one attribute, namely, acceptable terms and conditions. This factor is names as Business Terms.

Hence the satisfaction of restaurant partners towards the FOOD app is portrayed by the extracted six dimensions viz., Core function, Business autonomy, Order management, Customer Relationship Management, Synergic competitive strength, and Business terms.

\section{Reliability Test}

Cronbach alpha for six dimensions is computed to test the reliability of constructs.

Table 5 Cronbach alpha of Extracted Dimensions

\begin{tabular}{|l|c|}
\hline \multicolumn{1}{|c|}{ Dimensions } & Cron Bach alpha \\
\hline Core Function & .898 \\
\hline Synergic competitive strength & .786 \\
\hline Business autonomy & .749 \\
\hline CRM & .863 \\
\hline Order management & .886 \\
\hline
\end{tabular}

From the above table, it is seen that Cronbach's values for each dimension were greater than 0.7, which ensures reliability (Nunnally, 1978).

\subsection{Extraction of Implied Importance of Attributes and Dimensions}

Implied importance of attributes and dimensions are computed by revised IPA procedure (Deng et al., 2008) through logarithmic transformation and partial correlation method. The partial correlation coefficient for each attribute and dimensions and its rank are given as follows (Table $6)$. 
Table 6 Extraction of Implied importance of attributes and dimensions

\begin{tabular}{|c|c|c|c|c|c|}
\hline Satisfaction Attributes & $\begin{array}{c}\text { Implied } \\
\text { Importance }\end{array}$ & Rank & $\begin{array}{c}\text { Satisfaction } \\
\text { Dimension }\end{array}$ & $\begin{array}{c}\text { Implied } \\
\text { Importance }\end{array}$ & Rank \\
\hline Delivery (BS1) & 0.425 & 17 & \multirow{5}{*}{ Core Function } & \multirow{5}{*}{0.909} & \multirow{5}{*}{1} \\
\hline Reliable service (BS2) & 0.531 & 10 & & & \\
\hline Timely service (BS3) & 0.496 & 13 & & & \\
\hline order taking (BS4) & 0.463 & 15 & & & \\
\hline Online presence (BS5) & 0.56 & 9 & & & \\
\hline Attracting more customers (CN1) & 0.616 & 6 & \multirow{4}{*}{$\begin{array}{l}\text { Synergic } \\
\text { Competitive } \\
\text { Strength }\end{array}$} & \multirow{4}{*}{0.795} & \multirow{4}{*}{4} \\
\hline sales enhancement $(\mathrm{CN} 2)$ & 0.434 & 16 & & & \\
\hline Competitive advantage (CN3) & 0.576 & 8 & & & \\
\hline Customer rating (CN4) & 0.513 & 11 & & & \\
\hline Restaurant led promotion(BA1) & 0.626 & 5 & \multirow{4}{*}{$\begin{array}{l}\text { Business } \\
\text { Autonomy }\end{array}$} & \multirow{4}{*}{0.850} & \multirow{4}{*}{2} \\
\hline Promotion schemes (BA2) & 0.36 & 19 & & & \\
\hline Revenue sharing (BA3) & 0.608 & 7 & & & \\
\hline Stable T\&C (BA4) & 0.752 & 3 & & & \\
\hline Acting as customer interface (CRM1) & 0.582 & 7 & \multirow{3}{*}{$\begin{array}{l}\text { Customer } \\
\text { Relationship } \\
\text { Management }\end{array}$} & \multirow{3}{*}{0.803} & \multirow{3}{*}{3} \\
\hline Ownership of customer data (CRM2) & 0.483 & 14 & & & \\
\hline Customer loyalty-building (CRM3) & 0.505 & 12 & & & \\
\hline Order clarity (IM1) & 0.637 & 4 & \multirow{3}{*}{$\begin{array}{l}\text { Order } \\
\text { Management }\end{array}$} & \multirow{3}{*}{0.794} & \multirow{3}{*}{5} \\
\hline Order scheduling (IM2) & 0.411 & 18 & & & \\
\hline Order data management (IM3) & 0.307 & 20 & & & \\
\hline Acceptable T\&C (OT1) & 0.879 & 1 & Business Terms & 0.388 & 6 \\
\hline Credit transfer (OT2) & 0.858 & 2 & -- & -- & -- \\
\hline Total & 11.622 & & Total & 4.54 & \\
\hline Average & 0.55 & & Average & 0.7565 & \\
\hline
\end{tabular}

The mean for implied importance is 0.55 . Ten attributes are having higher importance than the mean. With a partial correlation value of 0.879 , acceptable terms and conditions are given first priority. Order data management activity has a partial correlation value of 0.307 , and it is given the least rank. In dimension, the mean is 0.7565 , and 5 dimensions are above the mean. The core function gets top priority with implied importance of 0.909 . With a partial correlation coefficient of 0.388 , acceptable terms \& conditions attract low priority.

\subsection{Revised importance satisfaction analysis of satisfaction dimensions}

Extracted satisfaction dimensions and implied importance are plotted in data-centered matrix (DCM) (Fig.4) and diagonal and scale centered matrix (DSCM) (Fig.5). Satisfaction for dimensions ranges from 1 to 7 , and it is plotted in the $\mathrm{X}$-axis. Implied importance value ranges from 0 to 1 , and it is plotted on $\mathrm{Y}$-axis. In the data-centered model, the crosshair point is fixed at the mean of satisfaction dimension (4.14) and mean of implied importance (0.76), and four quadrants are framed. In the diagonal and scale centered model, crosshair point is fixed at the mean of the $\mathrm{x}$-axis (3.5) and mean of the $\mathrm{Y}$-axis (0.5). And a diagonal line is drawn from the origin $(0,0)$ to the highest point $(7,1)$ so that along the diagonal line, the ratio between satisfaction dimension and importance is unity. In DSCM, the area above the diagonal line is considered as quadrant 1 , remaining areas are considered as quadrant 2,3 , and 4 as per scale centered partition. 
Catering to Caterers: Expectations and Satisfaction of Restaurant Partners from Food Online Order and Delivery (Food) Operator

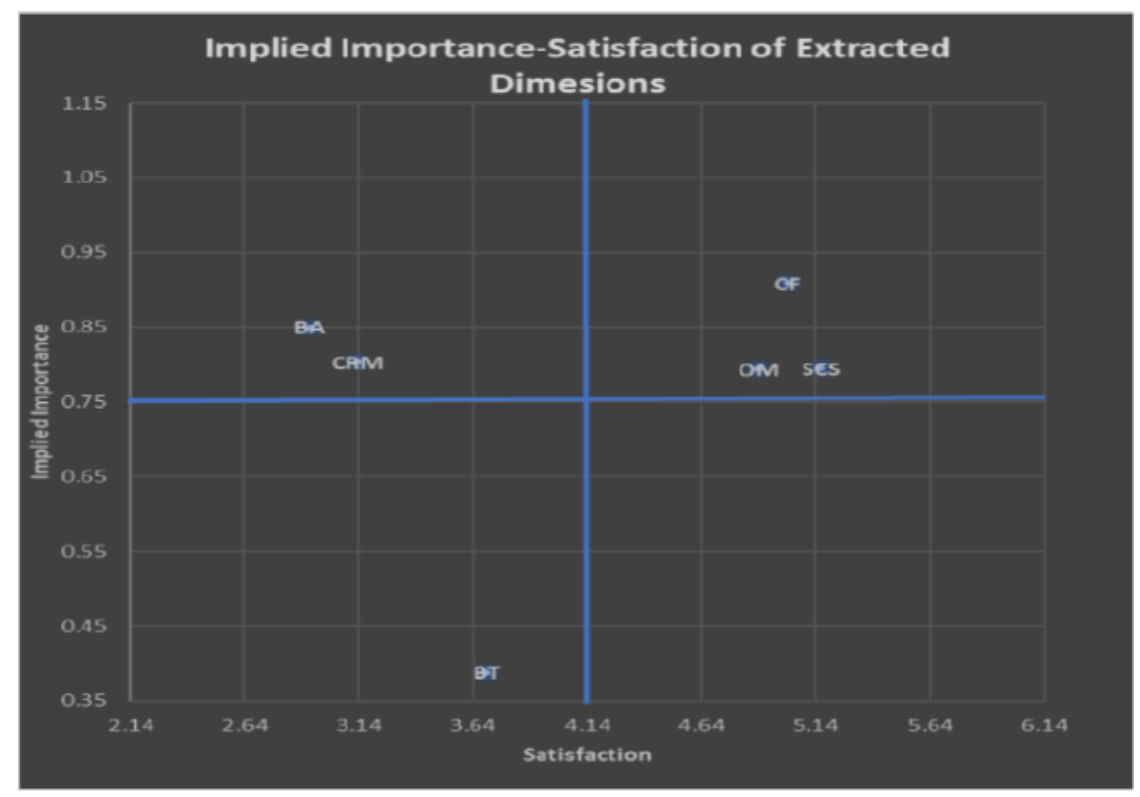

Figure 4: Data centered Model

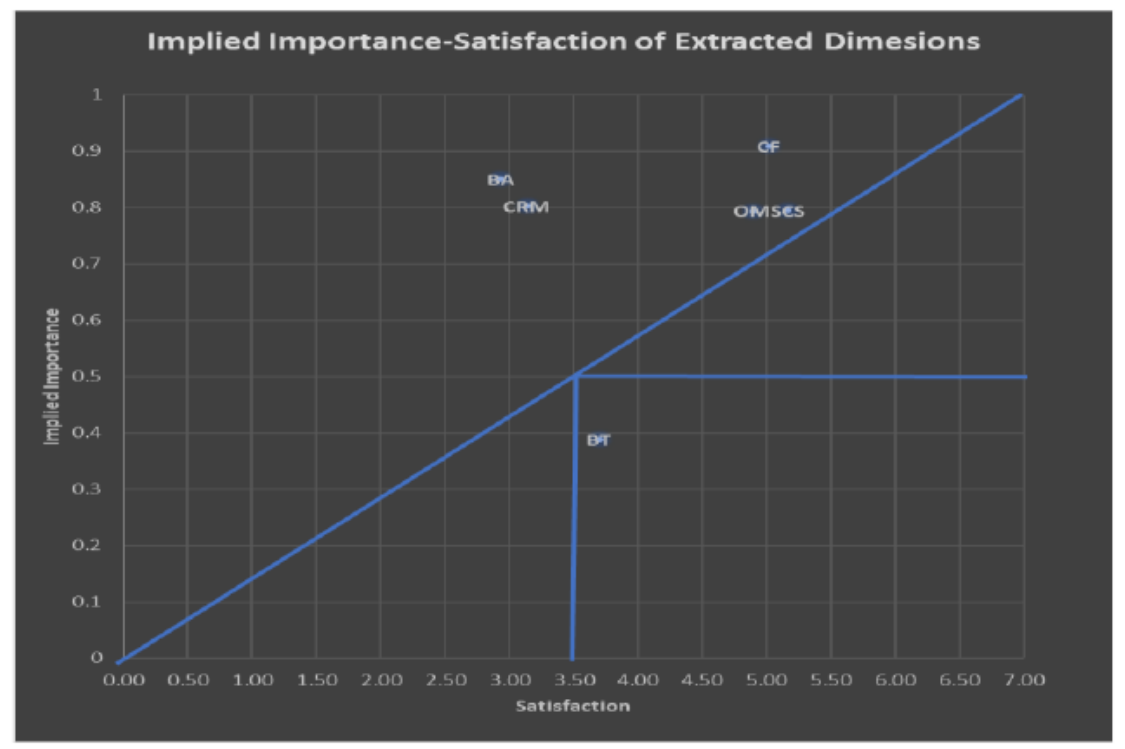

Figure 5 Diagonal and Scale Centered Model

Dimensions appearing in each quadrant in both models are given in the following table. It is observed that in DCM, quadrant 1, 2 dimensions are placed, and quadrant 2 has three dimensions. In quadrant 3 , only one dimension is appearing, and in quadrant four, no item is placed. In DSCM, five items are placed in Quadrant 1 area, only one dimension in quadrant 4, and none is in quadrant 2 and 4. 
Table 7 DCM and DSCM Comparison

\begin{tabular}{|l|c|c|c|c|c|c|}
\hline \multirow{2}{*}{ Satisfaction Attributes } & \multirow{2}{*}{$\begin{array}{c}\text { Satisfacti } \\
\text { on }\end{array}$} & \multirow{2}{*}{$\begin{array}{c}\text { Importanc } \\
\text { e }\end{array}$} & \multicolumn{2}{c|}{$\begin{array}{c}\text { Data Centered Model } \\
\text { Quadrant }\end{array}$} & $\begin{array}{c}\text { Decision } \\
\text { Centered Model }\end{array}$ \\
\cline { 4 - 7 } & Quadrant & Decision \\
\hline Core Function (CF) & 5.0195 & 0.909 & Q2 & Good & Q1 & Concentrate \\
\hline $\begin{array}{l}\text { Synergic Competitive } \\
\text { Strength (SCS) }\end{array}$ & 5.1667 & 0.795 & Q2 & Good & Q1 & Concentrate \\
\hline Business Autonomy (BA) & 2.9309 & 0.85 & Q1 & Concentrate & Q1 & Concentrate \\
\hline $\begin{array}{l}\text { Customer Relationship } \\
\text { Management (CRM) }\end{array}$ & 3.1382 & 0.803 & Q1 & Concentrate & Q1 & Concentrate \\
\hline Order Management (OM) & 4.8916 & 0.794 & Q2 & Good & Q1 & Concentrate \\
\hline Business Terms (BT) & 3.6992 & 0.388 & Q3 & LP & Q4 & Reduce \\
\hline Total & 24.85 & 4.54 & & & & \\
\hline Mean & 4.14 & 0.7565 & & & & \\
\hline
\end{tabular}

Items placed in each quadrant in both the models are compared in the following table. Items appearing in the same quadrant in each model are given in italics.

Table 8 Model Comparison of IPA of Satisfaction Dimensions

\begin{tabular}{|c|l|l|}
\hline Quadrant & \multicolumn{1}{|c|}{ Data centered Model } & \multicolumn{1}{c|}{ Diagonal and Scale Centered Model } \\
\hline Q1 & Concentrate Here & Concentrate Here \\
\hline & Business Autonomy & Business Autonomy \\
& CRM & $\begin{array}{l}\text { Core Function } \\
\text { Synergic Competitive strength } \\
\text { Order management }\end{array}$ \\
\hline Q2 & Keep up the good work & Keep up the good work. \\
\hline & Core Functions & \\
& Synergic Competitive strength & \\
\hline Q3 & Order management & Low Priority \\
\hline & Business Terms & \\
\hline Q4 & Possibly Overkill & Possibly Overkill \\
\hline & & Business terms \\
\hline
\end{tabular}

\section{Findings}

Business autonomy dimension and Customer relationship management dimension are placed in Q1 under both the models, and they deserve serious attention.

Core functions, Synergic competitive strength, and Order management are placed in Q2, signifying good work in DCM. But they are moved to Q1 in DSCM, and they need to attend.

Business Terms is considered a Q3-low priority factor in DCM, but it is moved to Q4 in DSCM, which classifies the dimension as a highly satisfied essential requirement.

\subsection{Revised Importance Satisfaction Analysis of Attributes}

Measured satisfaction and implied importance are plotted in data-centered matrix (DCM) (Fig.6) and diagonal and scale centered matrix (DSCM) (Fig.7). Satisfaction values range from 1 to 7 , and it is plotted in X-axis. Implied importance value ranges from 0 to 1 , and it is plotted in Y-axis. In the data-centered model, crosshair point is fixed at the mean of satisfaction (4.29) and mean of implied importance (0.55), and four quadrants are identified. In the diagonal and scale centered model, crosshair point is fixed at the mean of the X-axis (3.5) and mean of Yaxis $(0.5)$. And a diagonal line is drawn from the origin $(0,0)$ to the highest point $(7,1)$. Along the diagonal line, the ratio between satisfaction and importance is unity. In DSCM, the area 
Catering to Caterers: Expectations and Satisfaction of Restaurant Partners from Food Online Order and Delivery (Food) Operator

above the diagonal line is considered as quadrant 1 ; remaining areas are considered as quadrant 2,3 , and 4 as per scale centered partition.

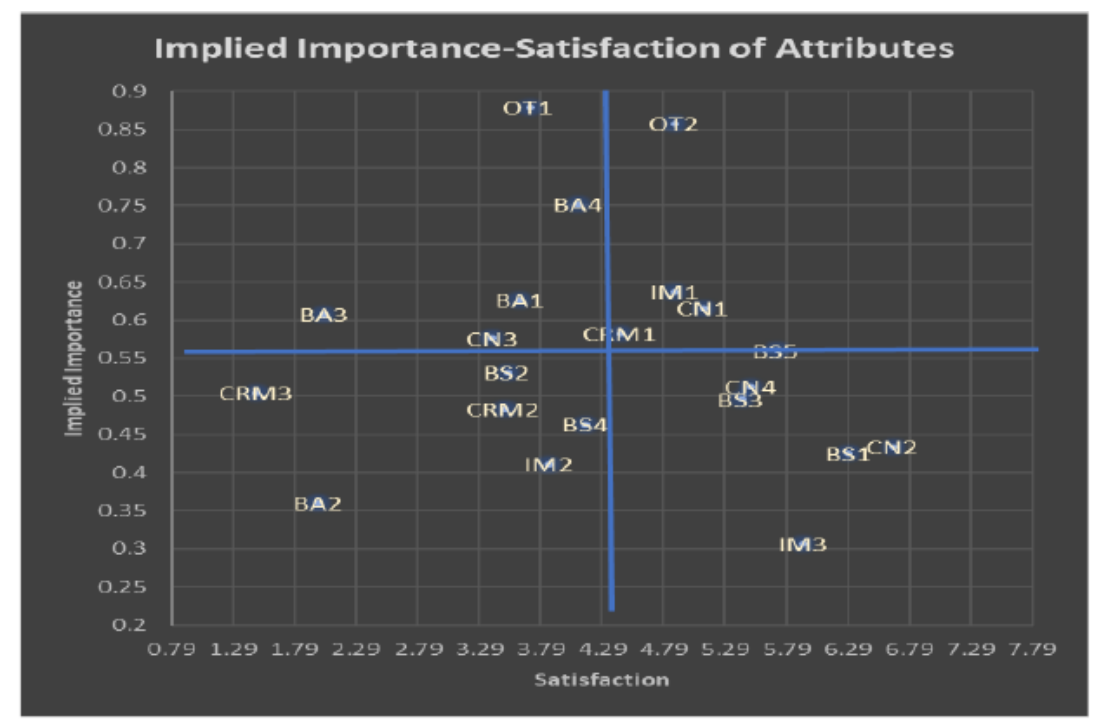

Figure 6 Data centered Model

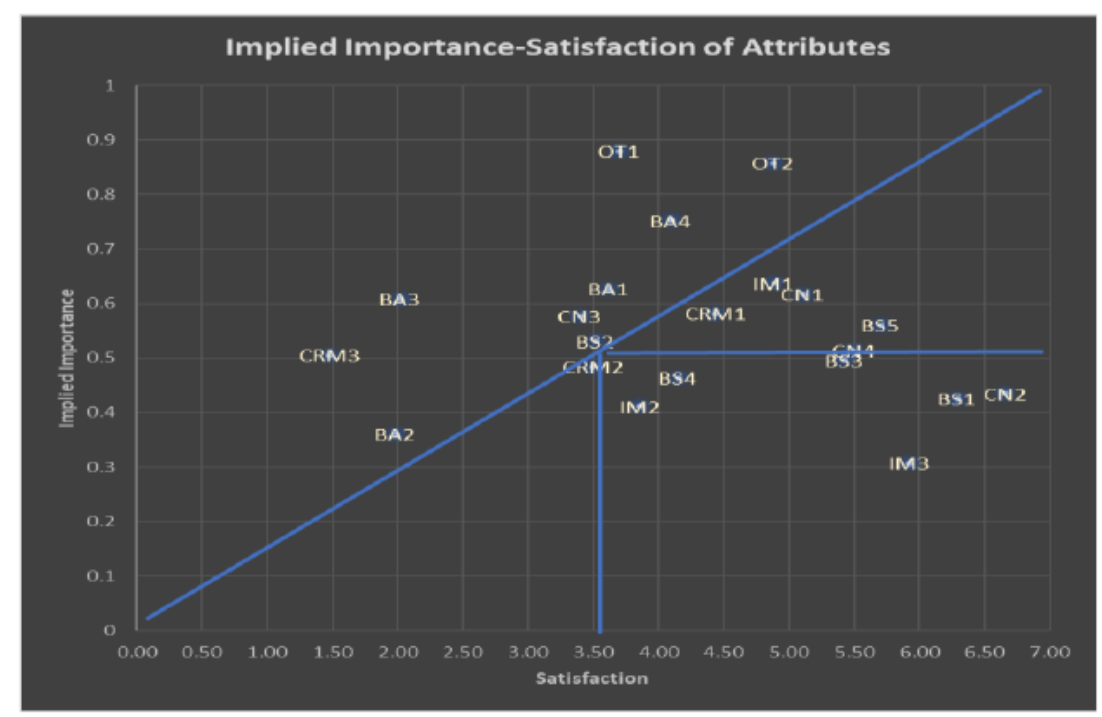

Figure 7 Diagonal and Scale Centered Model

Attributes appearing in each quadrant in both models are given in the following table (Table 9). It is observed that in DCM, quadrant 1, 2, and 4 have five attributes, and quadrant 3 has six attributes. In DSCM 9 items are placed in Quadrant 1 area, five attributes are in quadrant 2, 1 attribute is in quadrant 3 , and 6 attributes are placed in quadrant 4. 
Table 9 DCM and DSCM Model comparison for Attributes

\begin{tabular}{|l|c|c|c|l|l|l|}
\hline & & & \multirow{2}{*}{$\begin{array}{c}\text { Satisfa } \\
\text { Satisfaction Attributes }\end{array}$} & $\begin{array}{c}\text { Implied } \\
\text { Importance }\end{array}$ & Data Centered Model & \multicolumn{2}{c|}{$\begin{array}{c}\text { Diagonal and Scale } \\
\text { Centered Model }\end{array}$} \\
\cline { 5 - 7 } & & & $\begin{array}{c}\text { Quad } \\
\text { rant }\end{array}$ & $\begin{array}{c}\text { Recommendat } \\
\text { ion }\end{array}$ & Quadrant & $\begin{array}{c}\text { Recommendat } \\
\text { ion }\end{array}$ \\
\hline Delivery (BS1) & 6.29 & 0.425 & Q4 & Reduce & Q4 & Reduce \\
\hline Reliable service (BS2) & 3.52 & 0.531 & Q3 & LP & Q1 & Concentrate \\
\hline Timely service (BS3) & 5.42 & 0.496 & Q4 & Reduce & Q4 & Reduce \\
\hline order taking (BS4) & 4.15 & 0.463 & Q3 & LP & Q4 & Reduce \\
\hline Online presence (BS5) & 5.71 & 0.56 & Q2 & Good & Q2 & Good \\
\hline Attracting more customers (CN1) & 5.11 & 0.616 & Q2 & Good & Q2 & Good \\
\hline sales enhancement (CN2) & 6.66 & 0.434 & Q4 & Reduce & Q4 & Reduce \\
\hline Competitive advantage (CN3) & 3.40 & 0.576 & Q1 & Concentrate & Q1 & Concentrate \\
\hline Customer rating (CN4) & 5.50 & 0.513 & Q4 & Reduce & Q2 & Good \\
\hline Restaurant led promotion (BA1) & 3.62 & 0.626 & Q1 & Concentrate & Q1 & Concentrate \\
\hline Promotion schemes (BA2) & 1.98 & 0.36 & Q3 & LP & Q1 & Concentrate \\
\hline Revenue sharing (BA3) & 2.02 & 0.608 & Q1 & Concentrate & Q1 & Concentrate \\
\hline Stable T\&C (BA4) & 4.10 & 0.752 & Q1 & Concentrate & Q1 & Concentrate \\
\hline Acting as customer interface (CRM1) & 4.44 & 0.582 & Q2 & Good & Q2 & Good \\
\hline Ownership of customer data (CRM2) & 3.50 & 0.483 & Q3 & LP & Q3 & LP \\
\hline Customer loyalty-building (CRM3) & 1.48 & 0.505 & Q3 & LP & Q1 & Concentrate \\
\hline Order clarity (IM1) & 4.89 & 0.637 & Q2 & Good & Q2 & Good \\
\hline Order scheduling (IM2) & 3.86 & 0.411 & Q3 & LP & Q4 & Reduce \\
\hline Order data management (IM3) & 5.93 & 0.307 & Q4 & Reduce & Q4 & Reduce \\
\hline Acceptable T\&C (OT1) & 3.70 & 0.879 & Q1 & Concentrate & Q1 & Concentrate \\
\hline Credit transfer (OT2) & 4.88 & 0.858 & Q2 & Good & Q1 & Concentrate \\
\hline Total & 90.15 & 11.622 & & & & \\
\hline Average & 4.29 & 0.55 & & & \\
\hline
\end{tabular}

Items placed in each quadrant in both the models are compared in the following table (Table 10). Items appearing in the same quadrant in each model are given in italics.

Table 10 Model Comparison of IPA of Attributes

\begin{tabular}{|c|c|c|}
\hline Quadrant & Data Centered Model & \begin{tabular}{|l|} 
Diagonal and Scale Centered Model \\
\end{tabular} \\
\hline \multirow[t]{2}{*}{ Q1 } & Concentrate Here & Concentrate Here \\
\hline & $\begin{array}{l}\text { Competitive advantage } \\
\text { Restaurant led promotion } \\
\text { Revenue sharing } \\
\text { Stable T\&C } \\
\text { Acceptable T\&C }\end{array}$ & $\begin{array}{l}\text { Competitive advantage } \\
\text { Restaurant led promotion } \\
\text { Revenue sharing } \\
\text { Stable T\&C } \\
\text { Acceptable T\&C } \\
\text { Reliable service } \\
\text { Customer loyalty building } \\
\text { Promotion schemes } \\
\text { Credit transfer }\end{array}$ \\
\hline \multirow[t]{2}{*}{ Q2 } & Keep up the good work & Keep up the good work. \\
\hline & $\begin{array}{l}\text { Online presence } \\
\text { Attracting more customers } \\
\text { Acting as customer interface } \\
\text { Order clarity } \\
\text { Credit transfer }\end{array}$ & $\begin{array}{l}\text { Online presence } \\
\text { Attracting more customers } \\
\text { Acting as customer interface } \\
\text { Order clarity } \\
\text { Customer rating }\end{array}$ \\
\hline \multirow[t]{2}{*}{ Q3 } & Low Priority & Low Priority \\
\hline & $\begin{array}{l}\text { Ownership of customer data } \\
\text { Reliable service } \\
\text { order taking } \\
\text { Order scheduling } \\
\text { Customer loyalty building } \\
\text { Promotion schemes }\end{array}$ & Ownership of customer data \\
\hline \multirow[t]{2}{*}{ Q4 } & Possibly Overkill & Possibly Overkill \\
\hline & $\begin{array}{l}\text { Delivery } \\
\text { Timely service } \\
\text { Sales enhancement } \\
\text { Order data management } \\
\text { Customer rating }\end{array}$ & $\begin{array}{l}\text { Delivery } \\
\text { Timely service } \\
\text { sales enhancement } \\
\text { Order data management } \\
\text { Order taking } \\
\text { Order scheduling }\end{array}$ \\
\hline
\end{tabular}




\section{Findings}

The above table reveals the attribute position in both models. By comparing both models, priority, and nature of attributes are inferred.

\section{Basic Attributes}

Items in Q4 are basic functions, and its presence will not motivate, while absence will demotivate. Sales enhancement, delivery, timely service and order data management are the basic utility of the service, and they are placed in Q4 in both models. They cannot act as differentiators, but they need to be maintained with a good satisfaction level.

Restaurants are satisfied with timely service. Research on customer opinion also reveals the same. Gupta and Paul (2016); Pigatto et al., (2017) found that Online food order and delivery provide convenience, comfort, and timely service to customers. He et al. (2019) found that O2O food ordering employs equalizing methods in delivery service, and it makes customers waiting timeless significant. Correa et al. (2019) employed data mining and found that delivery time fulfillment is not affected by traffic conditions. Tan and Netessine (2017) studied the impact of table-top ordering technology and found that technology-based ordering reduced mealtime, increased sales per order, and enhanced sales productivity by $11 \%$.

\section{Good Work Attributes}

Items in Q2 are essential functions, and their presence will not have much impact. Online presence, customer attraction, order clarity, and customer management, are the attributes place in Q2 in both the models. They need to be maintained to attract more restaurants into the fold.

Gao and $\mathrm{Su}$ (2016) evaluated the utility of online to offline applications for FMCG retailers and found that it helps retailers to expand market coverage. He et al. (2019) found that due to the equalizing method of delivery service, each outlet can cater to the specific radius around them, and they can enhance their business scope.

\section{Concentrate Attributes}

Attributes in 3 are critical attributes. A higher level of satisfaction on those attributes will act as a motivator. Ensuring the creation of synergic competitive advantage, enabling the restaurant led promotion, relook on revenue sharing and designing acceptable stable terms \& conditions are the key weakness in both models which need to be concentrated.

In contrast, Yeo et al., (2017); Lindblom \& Lindblom (2017); Jiang \& Tian (2016) analyzed the strategic benefits to restaurants during 2017 and found that association with FOOD app is providing strategic strength to face the competition.

\section{Low Priority Attributes}

Items in Q3 are essential functions with lesser importance, and their presence will not have much impact. Restaurant partners did not give much importance to ownership of customer data in both models and placed them in Q3.

Literature provides a contrary view. Preoday's research explored the restaurant professional's opinion on FOOD apps. They found that $43 \%$ of restaurant professionals view third-party apps are withholding customer data and interfering in the direct relationship between them and customers (Hospitality Technology, 2018).

In addition to the common strength and weaknesses in both methods, the following variations are noted, which need to be inferred differently. 


\section{Maintain}

Customer rating is considered as a basic service in DCM while it is considered as good work under DSCM. It needs to be maintained. Order taking and scheduling are considered as basic in DSCM and it is placed under low priority in DCM. The status quo should be followed.

\section{Take Care}

Credit transfer is placed under good work in DCM while it is moved to the concentration area in DSCM. It needs attention. Reliable service, customer loyalty-building, and platform led promotions are placed under low priority in DCM. But they are in want of attention under DSCM.

Chengappa (2018) reported that several FOOD operators in India are laying out a variety of treats to lure the customer, and restaurant partners bear some of the trade discounts offered. Restaurant partners' satisfaction (1.98) towards a platform-wide promotion scheme is the second least among 21 factors that need attention.

\section{OUTCOMES OF THE STUDY}

- The study revealed 21 satisfaction attributes and six key dimensions of FOOD service.

- Revised IPA underscored the improvements needed to strategies a winning business model.

- Restaurants are eager to opt for FOOD app orders due to core services like online presence, order taking, delivery facility, and timely service. They are reporting improvements in the top line. They are not bothered about FOOD operator's involvement in dealing with customers, and they are satisfied with outsourcing customer management.

- Restaurants are longing for synergistic competitive strength and business autonomy. FOOD operators should have a relook on restaurant-customer loyalty-building, offers \&promotion schemes, and revenue-sharing schemes to entice more restaurants. They should provide stable terms of association.

- Preserving the business autonomy of restaurants, enhancing profitability, and providing competitive strength will cement the relationships in this business model.

\section{CONCLUSION}

Sustainability has gained attention as a prime focus area in the sharing economy (Tabcum, 2019). Every sustainable innovation should satisfy a want, and it should include the participation of all institutions. FOOD App, though, seems spicy and tasty business model, it should address the business aspirations of existing institutions in the ecosystems to ensure sustainability. Collison (2020) analyzed restaurant sales data and found that online order business is increasing revenue and reducing profitability. Helfat, \& Raubitschek (2018), identified, innovativeness, environmental scanning \& sensing capability, and integrative capability as the three types of dynamic capabilities for platform business operator to capture the value and stressed the importance of integrative capability.

The inclusion of restaurant partners into Innovative U-commerce FOOD App platforms doesn't mean the mere addition of names in the menu card. It connotes a strategic merger between brick and mortar stakeholders and click and order technology giants. This merger is possible only by a proper appreciation of take-home expectations of one another. Technology giants should appreciate the aspirations of restaurant partners and should dish out a "Win-Win" recipe. 


\section{MANAGERIAL IMPLICATIONS OF THE RESEARCH}

This work delves into the "take-away" expectations of restaurant partners and gives a first-hand account of their satisfaction quotient. Restaurant Partners who hold the majority stake in the food business market are also associating with FOOD operators, and a keen evaluation of their expectations will ensure mutual benefit. This enables FOOD managers to chalk out strategic directions.

The research exhibits mouth-watering toppings in the business association like online presence, wider reach, enhanced sales, and customer interface management. It also portrays the longing demands of restaurant partners. Recognizing business autonomy of restaurants in promotional activities and revenue sharing is the recipe for sustainability.

This study enables practicing managers of FOOD firms to device suitable business strategy by maximizing the benefits of positive attributes. They could work on the key weakness like pricing and revenue sharing schemes. This will result in manifesting fruitful association between technology giants and established restaurant houses.

\section{RESEARCH LIMITATIONS}

This study, though carried out methodically, the ensuing intricacies constrain it. The study is organized among restaurant partners in Tiruchirappalli City. As this research focuses on the business owners' perspectives on outsourcing food delivery service to the third-party online service provider, the results cannot be generalized or used for other aspects of the foodservice industry. Furthermore, the use of structured interview methods may imply incomplete or inaccurate information reflected in this study. It would also be advisable for future research to conduct qualitative research for cross-validation checks and quantitative research. Further, this cross-sectional study highlights the current situation, while a longitudinal study will throw more details on business dynamics in a rapidly evolving industry.

\section{REFERENCES}

[1] Abalo, J., Varela, J. and Manzano, V., 2007. Importance values for Importance-Performance Analysis: A formula for spreading out values derived from preference rankings. Journal of Business Research, 60(2), pp.115-121.

[2] Al Abid, F.B. and Karim, A.R., 2017, October. Cross-platform development for an online food delivery application. In 2017 International Conference on Computing Networking and Informatics (ICCNI) (pp. 1-4). IEEE.

[3] Babu.V., 2016. Online to Offline: Rise of O2O Commerce: Cover story: Business Today: https://www.businesstoday.in/magazine/cover-story/how-businesses-are-benefitting-from-theonline-boom/story/230733.html: Posted on April 24, 2016.

[4] Bacon, D.R., 2003. A comparison of approaches to importance-performance analysis. International Journal of Market Research, 45(1), pp.1-15.

[5] Bagla, R.K. and Khan, J., 2017. Customers' expectations and satisfaction with online food ordering portals. Prabandhan: Indian Journal of Management, 10(11), pp.31-44.

[6] Bajaj, K. and Mehendale, S., 2016. Food-delivery start-ups: In search of the core. Prabandhan: Indian Journal of Management, 9(10), pp.42-53.

[7] Chakraborty, D., 2019. Customer Satisfaction Towards Food Service Apps in Indian Metro Cities. FIIB Business Review, p.2319714519844651 
[8] Chen, C.D., Huang, C.K., Chen, M.J. and Ku, E.C., 2015. User's Adoption of Mobile O2O Applications: Perspectives of the Uses and Gratifications Paradigm and Service Dominant Logic. In PACIS (p. 253).

[9] Cheng, A., 2018.Millennials Are Ordering More Food Delivery, But Are They Killing The Kitchen, Too?:https://www.forbes.com/sites/andriacheng/2018/06/26/millennials-are-orderingfood-for-delivery-more-but-are-they-killing-the-kitchen-too/\#3a4df6ee393e: posted on June 26,2018

[10] Chengappa, S., 2018. In race for customers, food-delivery firms are offering big discounts, Business Line; https://www.thehindubusinessline.com/info-tech/in-race-for-customers-fooddelivery-firms-are-offering-big-discounts/article24822754.ece; Retrieved on October 10, 201

[11] Cho, M., Bonn, M.A. and Li, J.J., 2019. Differences in perceptions about food delivery apps between single-person and multi-person households. International Journal of Hospitality Management, 77, pp.108-116.

[12] Coates, J.F., 2001. A 21st century agenda for technology assessment. Technological Forecasting and Social Change, 67, pp.303-308.

[13] Collison, J. (2020). The Impact of Online Food Delivery Services on Restaurant Sales.

[14] Correa, J.C., Garzón, W., Brooker, P., Sakarkar, G., Carranza, S.A., Yunado, L. and Rincón, A., 2019. Evaluation of collaborative consumption of food delivery services through web mining techniques. Journal of Retailing and Consumer Services, 46, pp.45-50.

[15] Deng, W.J., Kuo, Y.F. and Chen, W.C., 2008. Revised importance-performance analysis: threefactor theory and benchmarking. The Service Industries Journal, 28(1), pp.37-51.

[16] Ennew, C.T., Reed, G.V. and Binks, M.R., 1993. Importance-performance analysis and the measurement of service quality. European journal of marketing, 27(2), pp.59-70.

[17] Feng, M., Mangan, J., Wong, C., Xu, M. and Lalwani, C., 2014. Investigating the different approaches to importance-performance analysis. The Service Industries Journal, 34(12), pp.1021-1041.

[18] Gao, F. and Su, X., 2016. Omnichannel retail operations with buy-online-and-pick-up-in-store. Management Science, 63(8), pp.2478-2492

[19] Gao, F. and Su, X., 2017. Omnichannel service operations with online and offline self-order technologies. Management Science, 64(8), pp.3595-3608.

[20] Gupta, T. and Paul, K., 2016. Consumer attitude towards quick service restaurants: a study across select quick service restaurants in Gurgaon. Indian Journal of Applied Research, 6(4), pp.639-641.

[21] He, Z., Han, G., Cheng, T.C.E., Fan, B. and Dong, J., 2019. Evolutionary food quality and location strategies for restaurants in competitive online-to-offline food ordering and delivery markets: An agent-based approach. International Journal of Production Economics, 21 5, pp.6172 .

[22] Helfat, C. E., \& Raubitschek, R. S. (2018). Dynamic and integrative capabilities for profiting from innovation in digital platform-based ecosystems. Research Policy, 47(8), 1391-1399. 
Catering to Caterers: Expectations and Satisfaction of Restaurant Partners from Food Online Order and Delivery (Food) Operator

[23] Hirschberg, C., Rajko, A., Schumacher, T. and Wrulich, M., 2016. The changing market for food delivery. Mckinsey: New York, NY, USA.

[24] Hongli, Z., 2018, January. Using Revised Importance Performance Analysis to Improve Service Quality of Airlines. In Proceedings of the 2018 2nd International Conference on Management Engineering, Software Engineering and Service Sciences (pp. 12-17). ACM.

[25] Hospitality Technology. 2018. 70\% of Consumers Prefer to Order Direct from Restaurants, Not Third-Party Services: https://hospitalitytech.com/70-consumers-prefer-order-direct-restaurantsnot-third-party-services; Posted on May 24, 2018.

[26] Huang, Y.K., Kuo, Y.W. and Xu, S.W., 2009. Applying Importance-performance Analysis to Evaluate Logistics Service Quality for Online Shopping among Retailing Delivery. International Journal of Electronic Business Management, 7(2).

[27] Jeng, C.R., Snyder, A.T. and Chen, C.F., 2019. Importance-performance analysis as a strategic tool for tourism marketers: The case of Taiwan's Destination Image. Tourism and Hospitality Research, 19(1), pp.112-125.

[28] Jeon, W.G., Lee, S.W. and Kim, J.J., 2017. Productivity Obstacle Factors Analysis For The Overseas Chemical Plant Utilizing The Revised IPA. Korean Journal of Construction Engineering and Management, 18(1), pp.17-26.

[29] Jiang, B. and Tian, L., 2016. Collaborative consumption: Strategic and economic implications of product sharing. Management Science, 64(3), pp.1171-1188.

[30] Kang, D. and Kim, S., 2018. The Effects of O2O Service Factors on Sequel Service Adoption: O2O Service Quality Dimensions and Perceived Fit, The 22nd Biennial Conference of the International Telecommunications Society: "Beyond the boundaries: Challenges for business, policy and society", June 24th - 27th, 2018, Seoul, Korea, International Telecommunications Society (ITS), Seoul

[31] Kapoor, A.P. and Vij, M., 2018. Technology at the dinner table: Ordering food online through mobile apps. Journal of Retailing and Consumer Services, 43, pp.342-351.

[32] Karthiyayini, N., Rajendran, C. and Kumaravel, M., 2018. Importance-performance analysis (IPA) for testing-and calibration-laboratories in India. Benchmarking: An International Journal, 25(4), pp.1232-1244.

[33] Keyt, J.C., Yavas, U. and Riecken, G., 1994. Importance-performance analysis: A case study in restaurant positioning. International Journal of Retail \& Distribution Management, 22(5), pp.35-40.

[34] Kimes, S.E. and Laqué, P.F., 2011. Online, mobile, and text food ordering in the US restaurant industry. Cornell Hospitality Report, 11(7), pp.6-15.

[35] Ku, G.C. and Mak, A.H., 2017. Exploring the discrepancies in perceived destination images from residents' and tourists' perspectives: A revised importance-performance analysis approach. Asia Pacific Journal of Tourism Research, 22(11), pp.1124-1138.

[36] Lee, E., 2019. Indoor environmental quality (IEQ) of LEED-certified home: Importanceperformance analysis (IPA). Building and Environment, 149, pp.571-581.

[37] Li, C., Mirosa, M., \& Bremer, P. (2020). Review of Online Food Delivery Platforms and their Impacts on Sustainability. Sustainability, 12(14), 5528. 
[38] Lin, S.P., Chan, Y.H. and Tsai, M.C., 2009. A transformation function corresponding to IPA and gap analysis. Total Quality Management, 20(8), pp.829-846.

[39] Lindblom, A. and Lindblom, T., 2017. De-ownership orientation and collaborative consumption during turbulent economic times. International journal of consumer studies, 41(4), pp.431-438.

[40] Liu, F., Xiao, B., Lim, E.T. and Tan, C.W., 2017. The art of appeal in electronic commerce: understanding the impact of product and website quality on online purchases. Internet Research, 27(4), pp.752-771

[41] Liu, W., Batra, R. and Wang, H., 2017. Product touch and consumers' online and offline buying: the role of mental representation. Journal of Retailing, 93(3), pp.369-381.

[42] Liu, Y., Guo, B., Du, H., Yu, Z., Zhang, D. and Chen, C., 2017. FooDNet: optimized on demand take-out food delivery using spatial crowdsourcing.

[43] Martilla, J.A. and James, J.C., 1977. Importance-performance analysis. Journal of marketing, 41(1), pp.77-79.

[44] Matzler, K., Sauerwein, E. and Heischmidt, K., 2003. Importance-performance analysis revisited: the role of the factor structure of customer satisfaction. The Service Industries Journal, 23(2), pp.112-129.

[45] Meenakshi, N. and Sinha, A., 2019. Food delivery apps in India: wherein lies the success strategy?. Strategic Direction.

[46] Meyersohn, N., 2018. Why Uber Eats and GrubHub partnerships are risky for restaurants : CNN Business: https://money.cnn.com/2018/03/28/news/companies/uber-eats-grubhub-deliveryapps/index.html : Posted on March 28, 2018

[47] Mody, M., Gomez, M., Searle, D., Muller, C. and Titherington, T., 2018. Boston Hospitality Review: Fall 2018.

[48] Mozeik, C.K., Beldona, S., Cobanoglu, C. and Poorani, A., 2009. The adoption of restaurantbased e-service. Journal of Foodservice Business Research, 12(3), pp.247-265.

[49] Munshi, A., 2019. Assessment of Competitiveness of Food-tech Start-ups in India. Indian Journal of Public Administration, 65(1), pp.201-224.

[50] O'Neill, M.A. and Palmer, A., 2004. Importance-performance analysis: a useful tool for directing continuous quality improvement in higher education. Quality assurance in education, 12(1), pp.39-52.

[51] Ormanovic, S., Ciric, A., Talovic, M., Alic, H., Jeleskovic, E. and Causevic, D., 2017. Importance-performance analysis: different approaches. Acta kinesiologica, 11, pp.58-66.

[52] Pan, Y., Wu, D. and Olson, D.L., 2017. Online to offline (O2O) service recommendation method based on multi-dimensional similarity measurement. Decision Support Systems, 103, pp.1-8.

[53] Park, S.H., Bae, M.A., Han, S.H., Cheng, S.Y., Kim, S.H. and Chang, K.J., 2019. Consumption Patterns and Importance-Performance Analysis of Home Meal Replacements by Level of Taurine-Related Nutritional Knowledge in Korean Adults. In Taurine 11 (pp. 205-213). Springer, Singapore 
Catering to Caterers: Expectations and Satisfaction of Restaurant Partners from Food Online Order and Delivery (Food) Operator

[54] Pigatto, G., Machado, J.G.D.C.F., Negreti, A.D.S. and Machado, L.M., 2017. Have you chosen your request? Analysis of online food delivery companies in Brazil. British Food Journal, 119(3), pp.639-657.

[55] Pornprasit, P. and Rurkkhum, S., 2019. Performance evaluation of community-based ecotourism: a case study in Satun province, Thailand. Journal of Ecotourism, 18(1), pp.42-59.

[56] Ray, A., Dhir, A., Bala, P.K. and Kaur, P., 2019. Why do people use food delivery apps (FDA)? A uses and gratification theory perspective. Journal of Retailing and Consumer Services, 51, pp.221-230.

[57] Rial, A., Rial, J., Varela, J. and Real, E., 2008. An application of importance-performance analysis (IPA) to the management of sport centres. Managing Leisure, 13(3-4), pp.179-188.

[58] Roh, M. and Park, K., 2019. Adoption of O2O food delivery services in South Korea: The moderating role of moral obligation in meal preparation. International Journal of Information Management, 47, pp.262-273.

[59] Romeo, P., 2018. 3 big changes looming for restaurants? : Operations: https://www.restaurantbusinessonline.com/operations/3-big-changes-looming-restaurants : Posted on October 19, 2018.

[60] Schroeder, S.A., Cornicelli, L., Fulton, D.C. and Merchant, S.S., 2018. Explicit versus implicit motivations: Clarifying how experiences affect turkey hunter satisfaction using revised importance-performance, importance grid, and penalty-reward-contrast analyses. Human dimensions of wildlife, 23(1), pp.1-20.

[61] Tabcum, S. J., 2019. The Sharing Economy Is Still Growing, And Businesses Should Take Note: https://www.forbes.com/sites/forbeslacouncil/2019/03/04/the-sharing-economy-is-stillgrowing-and-businesses-should-take-note/\#17a829fc4c33; accessed on October 10, 2019.

[62] Tan, T. and Netessine, S., 2017. At Your Service on the Table: Impact of Tabletop Technology on Restaurant Performance. Unpublished Dissertation, Cox Business School, Southern Methodist University, Dallas, Texas, U.S.A.

[63] Tandon, S., 2019. The revolt against food delivery apps : https://www.livemint.com/companies/start-ups/the-revolt-against-food-delivery-apps1566324255842.html : Posted on August 21, 2019.

[64] Tobing, R.D.H., 2016. A Food Ordering System with Delivery Routing Optimization Using Global Positioning System (GPS) Technology and Google Maps. Internetworking Indonesia Journal, 8(1), pp.17-21.

[65] Tonge, J. and Moore, S.A., 2007. Importance-satisfaction analysis for marine-park hinterlands: A Western Australian case study. Tourism Management, 28(3), pp.768-776.

[66] Verma, P. (2020). The effect of presentation, product availability and ease upon transaction reliability for online food delivery aggregator applications-moderated mediated model. Journal of Foodservice Business Research, 1-20.

[67] Wirth, S.R., 2018. The stats are in: Consumers are upping restaurant delivery: Consumer Trends : https://www.restaurantbusinessonline.com/consumer-trends/stats-are-consumers-are-uppingrestaurant-delivery: Posted on April 17, 2018. 
[68] Wu, T.J., Zhao, R.H. and Tzeng, S.Y., 2015. An empirical research of consumer adoption behavior on catering transformation to mobile O2O. Journal of Interdisciplinary Mathematics, 18(6), pp.769-788.

[69] Wyród-Wróbel, J. and Biesok, G., 2017. Decision Making on Various Approaches to Importance-Performance Analysis (IPA). European Journal of Business Science and Technology, 3(2), pp.123-131

[70] Xiao, S. and Dong, M., 2015. Hidden semi-Markov model-based reputation management system for online to offline (O2O) e-commerce markets. Decision Support Systems, 77, pp.87-99.

[71] Yang, Z., \& Peterson, R. T. (2002). The quality dimensions of Internet retail food purchasing: a content analysis of consumer compliments and complaints. Journal of Foodservice Business Research, 5(2), 25-46.

[72] Yeo, V.C.S., Goh, S.K. and Rezaei, S., 2017. Consumer experiences, attitude and behavioral intention toward online food delivery (OFD) services. Journal of Retailing and Consumer Services, 35, pp.150-162. 